This is a pre-copyedited, author-produced version of an article accepted for publication in Annals of Epidemiology following peer review. Published online August 24, 2008.

The final version was published in Annals of Epidemiology 2018 Nov;28(11):812-820 and is available at http://dx.doi.org/10.1016/j.annepidem.2018.08.006

(c) 2018. This manuscript version is made available under the CC-BY-NC-ND 4.0 license http://creativecommons.org/licenses/by-nc-nd/4.0

\title{
Review
}

\section{Challenges and common weaknesses in case-control studies on drug use and road traffic injury based on drug testing of biological samples}

Hallvard Gjerde ${ }^{\mathrm{a},{ }^{*}}$, Giovanni Romeo ${ }^{\mathrm{b}}, \mathrm{J} \emptyset \mathrm{rg}$ Mørland ${ }^{\mathrm{c}, \mathrm{d}}$

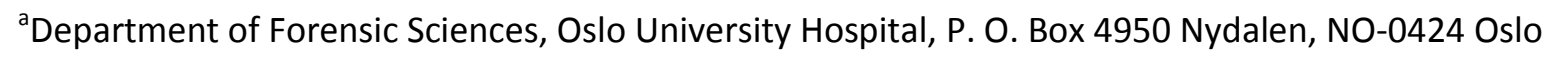
Oslo, Norway

${ }^{\mathrm{b}}$ Department of Biostatistics, Institute of Basic Medical Sciences, University of Oslo, P.O. Box 1110 Blindern, NO-0317 Oslo, Norway

${ }^{\mathrm{c}}$ Division of Health Data and Digitalization, Norwegian Institute of Public Health, P. O. Box 4404 Nydalen, NO-0403 Oslo, Norway

${ }^{d}$ Institute of Clinical Medicine, University of Oslo, P.O. Box 1171 Blindern, NO-0318 Oslo, Norway

*Corresponding author. Tel.: +47 23013045 .

E-mail address: hallvard.gjerde@ous-hf.no (H. Gjerde). 


\title{
Review
}

\section{Challenges and common weaknesses in case-control studies on drug use and road traffic injury based on drug testing of biological samples}

\begin{abstract}
The purpose of this review is to determine and discuss common weaknesses and errors in casecontrol studies on the association between drug use and road traffic crash injury among drivers and recommend improvements for future studies. A search for case-control studies published between 2000 and 2016 was performed using PubMed and other databases in addition to manual search. The used methodologies were compared with requirements and recommendations for case-control studies as well as current knowledge on the interpretation of drug concentrations in biological samples. Seventeen studies were identified. The major difficulties in the studies were related to likely selection bias, information bias and confounding. In some studies, the definition of drug exposure was different for controls than for cases, generating potentially serious errors in the odds ratio estimations. Other weaknesses include lacking explanation of the assessment of drug exposure, missing covariates, lacking description of statistical methods, and lack of discussion of bias and confounding. Recommendations for future studies are presented.
\end{abstract}

Keywords: Drugs; Road traffic crash; Road traffic injury; Case-control studies 


\section{Abbreviations and acronyms}

DRUID Driving Under the Influence of Drugs, Alcohol and Medicines Project

GHB Gammahydroxy butyric acid

ICADTS International Council on Alcohol, Drugs and Traffic Safety

RTC Road traffic crash

THC Tetrahydrocannabinol

TRID

Transport Research International Documentation 


\section{Introduction}

Case-control studies have sometimes been regarded as the optimal epidemiological method for studying the association between the use of alcohol or drugs, as exposure, and the involvement in road traffic crash (RTC), as outcome $(1,2)$. Drivers who are defined as cases are most often selected because they have been admitted to hospital due to serious injuries or because they were fatally injured in an RTC and therefore subject to post-mortem autopsy. They may also be selected from police records, insurance records, other databases and registries on crash-involved drivers, or by selfreported crash involvement. The controls are drivers representing the population of risk of becoming cases (3); they are most often selected among drivers in random road traffic from the same geographical area as the cases.

The exposure to alcohol and drugs may be determined in different ways: by analysing drugs in biological samples (blood, oral fluid, urine, or sweat), by self-reporting, or by using data from prescription registries. In this article we have only reviewed studies using biological samples to assess exposure.

An important requirement is that drug exposure is defined appropriately and accurately, and in the same way for cases and controls, to avoid significant information bias (4). If the accuracy and/or precision in the assessment of exposure is poor, misclassification will occur, causing noise in the statistics, which may obscure real associations between drug use and RTC involvement or create the appearance of unreal associations (4).

Covariates (independent variables) that should be included in the statistical analysis are driver variables that may explain some or all of the association between exposure and outcome.

Culpability (responsibility) studies are a special type of case-control studies where only crashinvolved drivers are studied. Drivers who contribute to the occurrence of their crash are then defined as cases and non-culpable as controls, assuming that non-culpable drivers are randomly selected from the driving population (5-8). Studies of that type will not be discussed in this article, but a number of issues will be relevant for those as well.

We have previously reviewed epidemiological studies on the association between drug use and RTC involvement (9). We then observed that many studies, particularly case-control studies, suffered from serious weaknesses. Some challenges when performing case-control studies on drug use and RTC involvement have been discussed in previous articles $(8,10,11)$. The aim of this review was to examine previous studies to assess the study design, statistical analysis of findings and discussion of results to identify weaknesses and challenges, and to propose improvements. Studies investigating only alcohol are not included.

\section{Methods}

\section{Selection of studies}

A broad search of studies published in the English language between 2000 and 2016 was performed. The following databases were included: PubMed, Google Scholar, Web of Science, ICADTS Database (www.icadtsinternational.com) and TRID Database (https://trid.trb.org). Search terms were: 'casecontrol drugs driving'; 'case-control road traffic accident'; 'drugs crash risk', or synonyms. In addition, a manual search was done by examining reference lists in relevant articles and reports. The used methodologies as well as the discussion of bias and confounding were compared with recommendations for case-control studies $(3,8,12)$.

\section{Assessment of selection bias}

The participation rate or included proportion of the total cohort was recorded. 


\section{Assessment of drug exposure and information bias}

The type of biological sample used to assess drug exposure among cases and controls was recorded. If the type of biological sample used for cases was different from the type used for controls, we assessed whether the definition of exposure was equivalent for cases and controls. We also examined whether the exposure definition was explained, i.e. whether it reflected possible drug intoxication/impairment or drug intake during the last day, days or weeks.

\section{Assessment of statistics including covariates}

The descriptions of the statistical methods were assessed to determine whether sufficient details were presented so that other researchers could reproduce the statistical assessment. We recorded the included covariates.

\section{Results}

\section{Overview of case-control studies during 2000-2016}

A total of 17 case-control studies on the association between drug use and being injured in a road traffic crash based on analysis of biological samples were identified (Table 1); 12 of the reports were published in peer-reviewed journals.

\section{Selecting cases and controls}

Injured drivers were included in eight studies; killed drivers in eight studies, and both injured and killed in one. No study selected only drivers who were responsible for the crash as cases. However; in two studies, drivers involved in single vehicle crashes were analysed separately; they were then regarded as culpable for the crash $(13,14)$. Only drivers of cars and vans were included in six studies.

Drivers in random road traffic were selected as controls in 14 studies. In one study, patients who had been hospitalized for other reasons than RTC involvement were selected as controls; whereas in two studies, drivers were selected at petrol stations. Collection of controls was not in any study performed on the actual RTC sites, but in the same geographical areas in some studies.

The participation rates for cases ranged from $17 \%$ to $100 \%$. It was lower than $80 \%$ or not presented among injured drivers who participated voluntarily in three studies, one included both injured and killed drivers. Fatally injured drivers were included as cases because toxicological testing was requested by the police in eight other studies; the inclusion rate was less than $80 \%$ in six and not presented in two of those studies. The participation rates for controls ranged from about $45 \%$ to $100 \%$; it was lower than $80 \%$ in 11 studies. Data from several countries were merged in two studies.

The participation rates were in general lower when collecting blood samples than when collecting oral fluid samples from controls.

\section{Defining and measuring exposure}

Drug exposure was assessed by analysing blood samples from cases and oral fluid samples from controls in seven studies; in two of those, blood samples were analysed from a minor proportion of the controls instead of oral fluid. Three studies had analysed only blood samples, two studies only urine samples. The remaining five studies had used a combination of urine and blood samples from cases, and either oral fluid or blood and urine, in different proportions than for cases, among controls. Self-reported data was used as supplement in one study, and samples of sweat in one study.

Only one of the studies used cut-off concentrations for drugs that had been documented to be associated with significant impairment of psychomotor and cognitive functions; that study compared three cut-off concentrations for THC (15), including a limit of $5 \mathrm{ng} / \mathrm{mL}$ in blood. A review of previous 
experimental studies concluded that THC plasma concentrations of 7-10 ng/mL gave an impairment corresponding to a blood alcohol concentration of $0.5 \mathrm{~g} / \mathrm{L}(16)$; this corresponds to THC concentrations in whole blood of about $5 \mathrm{ng} / \mathrm{mL}$.

Five case-control studies that collected blood from cases and oral fluid from controls had used cut-off concentrations that were defined as equivalent in oral fluid and blood (13, 14, 17-19). When using equivalent cut-off concentrations, the prevalence of positive drug test results is expected to be the same regardless of whether oral fluid or blood is analysed $(20,21)$.

Only one substance class was analysed in one of the studies (22); multidrug use or combinations of a drug with alcohol was then disregarded.

\section{Statistical assessment and covariates}

Controls had been matched with cases regarding important covariates in three studies. Of the other studies, only bivariate data analysis (i.e., calculating crude odds ratios) was used in four studies and multivariable analysis in 10 studies.

One study had included only age as covariate; whereas most studies had included age and sex. Some studies had also included alcohol or drug use, time period, season, geography, and urbanity. One study had included non-stop driving time and years of driving.

The simultaneous use of more than one psychoactive substance was handled in different ways in the 10 multivariable analyses. Three studies had included all psychoactive substances as covariates during analysis (or similar substances grouped together) (23-25); two had also included substance interaction variables $(23,25)$. The logistic regression analysis was simplified by using sub-samples comparing subjects who tested positive for only the investigated substance or substance group (as exposure) in six studies. Of those ones, the reference group was subjects who did not test positive for alcohol or any drug in two studies (all drivers that had used any other psychoactive substance were excluded from the statistical analysis), whereas the reference group was not defined in four studies. When data for a drug or drug group were presented, several studies did not specify whether the data represented drivers testing positive for only the drug in question, or whether the drivers may also have tested positive for other substances. Altogether, the statistically assessment of the findings was not described sufficiently detailed in about half of the studies.

\section{Discussion}

All reviewed case-control studies on the association between drug use and being injured in a RTC had weaknesses. Many studies had potentially significant selection bias. Information bias was also common, particularly in studies based on different types of biological samples from cases than from controls, and in studies where analytical results from blood, urine or oral fluid samples were mixed. Some studies had not included significant covariates in the statistical analysis. The impact of those weaknesses is that the calculated odds ratios were likely to be inaccurate; the errors may in some cases have caused incorrect conclusions on the risk for crash involvement after drug use (8). This finding was not unexpected, as case-control studies tend to be more susceptible to biases than other analytical epidemiological designs; selection bias, information bias and confounding are important causes of inconsistent or contradictory results (12).

Most studies did not explain what the classification of drug exposure meant in terms of possible impairment/intoxication or time since last drug intake, and many studies did not describe the statistical methods with sufficient details, or discuss significant study limitations. 


\section{Selection of cases and controls}

Non-participation is a common challenge in survey research on sensitive issues $(26,27)$. When selecting controls from random road traffic, drivers were in most studies stopped by police officers and asked to participate in a study. There is considerable variation in public trust towards the police in different countries (28). Some drivers may therefore have believed that the survey was not completely anonymous, or they feared that the police officer may recognize and report any use of alcohol or drugs. It can thus be expected that the prevalence of alcohol or drug use among those who refused to participate in this type of study was higher than among those who were willing to provide a biological sample for testing (8).

The type of drivers selected as controls was not optimal in some studies. For example, patients who had been hospitalized for other reasons than RTC were selected as controls in one study (29). Injuries and illness is in many cases associated with alcohol or drug use; therefore, it is likely that those patients did not represent random drivers and the odds ratio may be under-estimated in those studies. They should instead be regarded as another patient cohort, not controls. Drivers at petrol stations were used as controls in two studies $(22,30)$. It is likely that some drivers who were under the influence of alcohol or drugs may have avoided filling petrol when there was a chance of being observed and reported to the police. Therefore, the odds ratio may have been over-estimated in those studies.

None of the studies selected controls at crash sites. Reasons may be high speed limits that are not in line with safety requirements for the researchers, insufficient space for collecting controls, or lack of priority. If controls were selected at other sites, they might represent a somewhat different population than RTC involved drivers.

If injured drivers were included as cases and participation was voluntary, it is also expected that the prevalence of alcohol and drugs was under-estimated in studies with high refusal rate, contributing to under-estimation of the odds ratio for RTC involvement. Low participation rate may also be caused by the fact that treatment of injuries was prioritized higher than recruitment to a research project; however, this may not necessarily cause a significant selection bias.

Another likely selection bias is that drivers with minor injuries were not admitted to hospital for treatment and therefore not included, while the most severely injured drivers may have needed intensive care (or were unconscious) and could therefore not be asked to participate.

If drivers killed in road traffic crashes were studied as cases, only those who were subject to legal autopsy or blood sampling were included. It is likely that the police may have avoided requesting autopsy or blood sampling if there was no legal reason to do so, unless the law explicitly stated that autopsies should be performed for statistical reasons. If only a proportion of crash-involved drivers were tested for use of alcohol or drugs, the decision on whom to test may be based on suspicion of alcohol or drug use; therefore, the prevalence of alcohol or drugs in samples from cases may be overestimated causing over-estimation of the crash risk. This was likely in at least six studies.

The most significant over-estimation of the odds ratios for RTC involvement had probably occurred in six studies with low participation rates among controls and cases selected by the police for alcohol and drug testing. However, the assessment of drug exposure was not equivalent for cases and controls in three of those studies, making it impossible to conclude whether the odds ratios were significantly over or under-estimated, but they are probably inaccurate.

Crash-involvement does not mean crash responsibility. In some crashes between a drug-impaired driver and a sober driver, the driver who was injured or killed and therefore most likely included in the study as crash-involved might not have been the one who was responsible for the collision. We would expect that the association between drug use and crash responsibility would be higher than 
for merely crash involvement. Few studies distinguished between drivers involved in single and multiple vehicle crashes $(13,14)$; those involved in single vehicle crashes were then defined as most likely responsible for the crash.

\section{Assessing drug exposure}

An important requirement is that drug exposure must be defined appropriately, accurately, and in the same way for cases and controls to avoid information bias (4). Drug concentrations in blood reflect better than any other biological samples drug use that may affect cognitive and psychomotor functioning. Therefore, blood samples should ideally be analysed both for cases and controls. It has earlier been assumed that the presence of a drug in a sample of oral fluid reflects presence in blood (31-33); therefore, oral fluid was collected instead of blood samples in many studies. However, there are large inter- and intra-individual variations in the drug concentration ratio between oral fluid and blood $(34,35)$. The use of oral fluid samples will thus introduce an additional variability, which may cause misclassification of drug exposure: a drug may be detected in oral fluid while it is not detectable in blood (i.e., below the cut-off concentration), or vice versa. We have previously found that $2-64 \%$ of drivers who tested positive for different psychoactive drugs in oral fluid tested negative in blood $(36,37)$. The misclassification may either be systematic, by random, or both, and may obscure any associations between drug use and crash involvement or create the appearance of unreal associations. To reduce or eliminate systematic misclassification, drug concentration cut-offs in oral fluid that are equivalent to cut-off concentrations in blood were used in some studies, but random classification errors would still occur due to the variation in drug concentration ratios between oral fluid and blood for individuals.

Methods to minimize the extent of this type of misclassification of drug exposure should be considered. A possible method might be to include self-reported drug use in addition to the drug test, even though the data might not always be reliable. This should only be included if also used for drivers defined as cases (i.e., crash-involved). Self-reported drug use may be of particular interest when studying the population of drug-using drivers as a whole, or habitual drug using drivers, where drug testing alone is insufficient. Self-reported information about the driver's attitude to driving after using the drug in question might also provide valuable information.

When studying drug exposure among cases, samples of blood or oral fluid should be taken from cases immediately after the crash. If there is a delay, the drug concentration may decline due to distribution, metabolism and excretion. The decrease in concentration is particularly fast for GHB, THC and cocaine (38-41). If using blood samples taken during post-mortem autopsy several days after the fatal RTC, the drug concentration in blood may not reflect the drug concentration at the time of the crash due to post-mortem re-distribution (42-44).

Low cut-off concentrations in blood, oral fluid or urine were used in most studies, thereby classifying drivers who had used drugs within the last day/days/weeks as being drug exposed. The advantage with choosing a low cut-off concentration is that the number of drug-exposed cases and controls will be larger, thus improving the statistical power. However, then a positive drug test will not necessarily indicate impairment or intoxication. None of the studies included in this review investigated specifically drug intoxicated drivers; except one study that distinguished between high and low concentrations for THC (15).

If blood samples are analysed from both cases and controls, the drug concentrations should be taken into account in the statistical analysis, rather than dichotomizing using a more or less arbitrary cutoff. If the aim is to study the crash risk after taking a dose that is likely to cause intoxication or the feeling of 'high' or 'stoned', i. e. a dose which may be accompanied by impaired cognitive and psychomotor functioning, the exposure may be defined as a drug concentration in blood above a limit that has been documented to impair cognitive or psychomotor functions in previous 
experimental studies. Claiming a causal relationship between drug use and crash involvement would become more plausible if a concentration or dose-response relationship is found.

Detected drugs within the same drug class were in most studies grouped together, such as benzodiazepines and opioids, in order to obtain large number of drug-exposed cases and controls to improve statistical power. The cut-off concentrations for the single drugs included in the drug group were in most studies not associated with the same degree of impairment in psychomotor and cognitive tests. Data on equipotent doses of e. g. benzodiazepines (45-47) and opioids (48-50) have been published. Based on these doses and pharmacokinetic properties, equipotent drug concentrations have been estimated, and drug concentrations can be converted to diazepam equivalents for benzodiazepines and morphine equivalents for opioids (51). This procedure would have improved the quality of the odds ratio estimations for benzodiazepines and opioids when grouped together.

Sometimes, different substances were compared, e.g. the RTC risk associated with using one type of benzodiazepine was compared with the risk associated with using another type of benzodiazepine or an opioid. In order to obtain comparable data, the cut-off concentrations should be equivalent regarding impairing effect of those substances in experimental studies.

\section{Statistical assessment and covariates}

Some studies calculated only the bivariate (crude) odds ratio. This may cause significant errors, as the probability for crash involvement is also related to age, sex, and time of day/week, as well as other factors. The investigators should consider including covariates that are distributed differently among exposed and non-exposed drivers; this should be based on plausible hypotheses.

Also the use of other psychoactive substances (in addition to the drug in question) is very important. This has been handled in different ways, which have affected the calculated odds ratio. The most common method has been to study only one substance (or substance group) at a time, excluding drivers testing positive for other drugs, or ignoring other drug findings. Excluding drivers that had used other drugs reduced the number of individuals included in the analysis, and consequently also decreased the statistical power, whereas ignoring other drug findings will make the interpretation of the odds ratio more difficult as it will be based on drivers with single drug use and multi-substance use.

The annual driving distance had had not been included as covariate in any study. Low annual mileage is associated with high crash risk $(52,53)$ and should therefore be considered as covariate. However, this covariate cannot easily be studied for killed drivers.

Some likely confounders that are difficult or impossible to include are impulsivity and risk-taking personality. Previous studies have found associations between the use of illicit drugs and risk-taking personality (54-58), which may be associated with high crash risk also in the absence of drug use. In addition, risk-taking behaviour might again be increased after using some types of drugs. Attitudes in the society towards driving after using alcohol or drugs may also affect the calculated odds ratio (59).

If the sample size is small and many covariates are included in the statistical analysis, one important challenge is to avoid empty cells in the contingency tables. It has previously been recommended to replace zero in such cells by $1 / 2(60)$. This was done in one study (61). However, this may also lead to incorrect odds ratio estimations, so we suggest that this is not done. Instead, consider excluding those covariates from the data analysis.

If including alcohol and other single drugs as covariates, the probability of empty cells increases, particularly because some drugs found among cases are rarely detected among controls. One way to avoid empty cells is to group similar compounds, e.g. benzodiazepines, into one covariate; another 
possibility is to group the use of other substances than the one being investigated into a single covariate.

Three studies selected controls by matching age and sex with cases, in one study geographical area and season were used as matching criteria, whereas in another study, time period and type of vehicle was used. However, matching in a case-control design does not control confounding but does increase efficiency, at the cost of being unable to consider the matching variable as a main effect or effect modifier. Matching may in fact introduce confounding by the matching factors even when it did not exist in the source population (62). Multivariable analysis was therefore used in two of those studies to control for this effect.

\section{Conclusions and recommendations}

Many of the challenges and weaknesses observed in this review can be overcome or reduced. A wellperformed case-control study of drug use and RTC injury may provide important information on the association between drugs and RTC involvement among drivers in actual road traffic and may supplement findings in experimental findings on the effect of drug doses on cognitive and psychomotor functions that are needed to drive safely. As there are a number of challenges with case-control studies, other research methods that may eliminate some of the challenges should be considered.

Culpability (responsibility) study designs may theoretically mitigate some of the concerns regarding both selection bias and information bias, because blood samples can be collected and analysed from both parties involved in crashes. Thereby, the measurement of drug exposure is equal for cases and controls. Alcohol and drug testing may be performed for both parties involved in a road traffic collision; thereby the selection bias may be reduced. However, it may be difficult to include a sufficiently high number of RTCs to get good statistical power. There are a number of challenges with culpability studies as well, particularly obtaining unbiased assessment of crash culpability and contextual contributions to crash risk $(6,8)$.

Cohort studies may be used to compare RTC involvement among drivers who are using medicinal drugs with drivers who are not, or by comparing RTC involvement during periods when the drivers are using the drugs with periods with no use in a case-crossover study design. This can be done by coupling data from prescription registries with RTC registries $(63,64)$ or using self-reported data. Some challenges regarding selection bias will then be eliminated. If using a case-crossover design, some key confounders can also be eliminated $(65,66)$. However, there are challenges regarding the accuracy of recorded drug exposure; in studies based on prescription databases it is not known whether the driver actually took the medicinal drug and whether the taken dose was correct; it is only known that the medicinal drug was dispensed at a pharmacy. It is neither known if alcohol or other psychoactive drugs were taken. If based on self-reported data, incorrect reporting of alcohol and drug use and crash involvement may be a problem.

Our recommendations for case-control studies on drug use and traffic injury based on testing of biological samples are:

1. The project team should include researchers with competence within the fields of pharmacology, toxicology, statistics, epidemiology, and well as drug analysis to avoid many common errors and weaknesses observed in previous studies.

2. Define the selection criteria for cases clearly; efforts should be taken to minimize selection bias. If studying drivers injured in RTC, select them systematically or by random, as long as it does not interfere with medical treatment. Specify whether cases are selected because of crash involvement 
or crash responsibility. Present participation rate or the included proportion of the total cohort, and discuss any effects of possible selection bias on calculated odds ratios.

3. Define selection criteria for controls clearly; the appropriateness of the control group should be critically assessed. Learn from previous studies how to obtain highest possible participation rates as it is essential to avoid that alcohol and drug using drivers refuse to participate. Discuss possible selection bias on the calculated odds ratios.

4. Specify whether the study objective is to investigate the crash risk among (a) drivers being under the influence of drugs (intoxicated or 'high'); or (b) drivers who have detectable trace of the drug in a biological sample (blood, oral fluid, urine, or sweat). It is possible to study subgroups (a) and (b) in the same investigation. If the aim is to study the odds ratio for crash involvement during acute impairment/intoxication, drug concentrations above the selected cut-off concentration in the biological sample should be found to impair psychomotor and cognitive functions in experimental studies.

5. Use the same criteria for defining drug exposure for cases and controls; justify and explain the criteria to avoid misunderstanding by non-pharmacologists.

6. Collect blood samples from cases and controls, if possible, because blood is the best type of biological sample for assessment of drug-related impairment at the time of sample collection. If using oral fluid sample from controls and blood samples from cases, drug exposure is not defined equally. In that case, equivalent definitions of exposure should be used and potential consequences of using different sample types must be discussed. Collecting additional data on drug intake, such as selfreported use, may be considered to reduce misclassification of drug exposure. If analysing urine samples to detect alcohol and drug exposure, select urine from both cases and controls. Collect biological samples from cases as soon as possible after the crash, record the time from crash to sample collection, and discuss the impact of the time lapse between RTC and sample collection on concentrations of alcohol and drugs. If using post-mortem autopsy samples, discuss the impact of alcohol and drug concentration changes.

7. If the numbers of cases and controls are sufficiently high and blood samples are analysed, calculate the odds ratio for RTC involvement for drug concentration intervals in blood, similarly to studies previously performed for alcohol.

8. If comparing drugs or studying the association between drug groups (e.g. benzodiazepines or opioids) and RTC involvement, use cut-off concentrations reflecting use of equipotent doses.

9. The proportion of drivers involved in single vehicle and multiple vehicle crashes should be presented. The odds ratio for those groups may be calculated separately. The proportion of drivers of different motor vehicle types should be presented; alternatively may only car/van drivers or motorcycle/moped drivers be included.

10. For the regression analysis, the process of selecting covariates and interaction variables should be described. We recommend that other psychoactive substances (single substances or grouped together) are included as covariates in the data analysis and calculated odds ratios for all covariates are presented. The effects of potentially significant covariates that are not included in the statistical analysis should be discussed.

\section{Acknowledgements and funding}

This research did not receive any specific grant from funding agencies in the public, commercial, or not-for-profit sectors. 
Author contribution: all authors have participated in conception and design or analysis and interpretation of the data; drafting the article or revising it critically for important intellectual content; and approval of the final version.

\section{References}

1. Berghaus G, Ramaekers JG, Drummer OH. Demands on scientific studies in different fields of forensic medicine and forensic sciences. Traffic medicine--impaired driver: alcohol, drugs, diseases. Forensic Sci Int 2007;165(2-3):233-7.

2. Houwing S, Mathijssen R, Brookhuis KA. Case-control studies. In: Verster JC, Pandi-Perumal SR, Ramaekers JG, de Gier JJ, editors. Drugs, Driving and Traffic Safety. Basel, Switzerland: Birkhäuser Verlag AG; 2009. p. 107-20.

3. Schulz KF, Grimes DA. Case-control studies: research in reverse. Lancet 2002;359(9304):431-4.

4. Grimes DA, Schulz KF. Bias and causal associations in observational research. Lancet 2002;359(9302):248-52.

5. Robertson MD, Drummer $\mathrm{OH}$. Responsibility analysis: a methodology to study the effects of drugs in driving. Accid Anal Prev 1994;26(2):243-7.

6. Salmi LR, Orriols L, Lagarde E. Comparing responsible and non-responsible drivers to assess determinants of road traffic collisions: time to standardise and revisit. Inj Prev 2014.

7. Lenguerrand E, Martin JL, Moskal A, Gadegbeku B, Laumon B. Limits of the quasi-induced exposure method when compared with the standard case-control design. Application to the estimation of risks associated with driving under the influence of cannabis or alcohol. Accid Anal Prev 2008;40(3):861-8.

8. Kim JH, Mooney SJ. The epidemiologic principles underlying traffic safety study designs. Int J Epidemiol 2016;45(5):1668-75.

9. Gjerde $H$, Strand $M C$, Mørland J. Driving under the influence of non-alcohol drugs - an update. Part I: epidemiological studies. Forensic Sci Rev 2015;27(2):89-114.

10. Houwing S, Hagenzieker M, Mathijssen RP, Legrand SA, Verstraete AG, Hels T, et al. Random and systematic errors in case-control studies calculating the injury risk of driving under the influence of psychoactive substances. Accid Anal Prev 2013;52:144-53.

11. Ramaekers JG. Pitfalls in estimating drug-related crash risk. Trends Pharmacol Sci 2003;24(3):114-5.

12. Kelsey JL, Whittemore AS, Evans AS, Thompson WD. Methods in Observational Epidemiology, 2nd Ed. New York, NY: Oxford University Press; 1996.

13. Gjerde H, Normann PT, Christophersen AS, Samuelsen SO, Mørland J. Alcohol, psychoactive drugs and fatal road traffic accidents in Norway: a case-control study. Accid Anal Prev 2011;43(3):1197-203.

14. Gjerde H, Christophersen AS, Normann PT, Mørland J. Associations between substance use among car and van drivers in Norway and fatal injury in road traffic accidents: a case-control study. Transp Res Part F Traffic Psychol Behav 2013;17:134-45. 
15. Kuypers KP, Legrand SA, Ramaekers JG, Verstraete AG. A case-control study estimating accident risk for alcohol, medicines and illegal drugs. PLoS One 2012;7(8):e43496.

16. Grotenhermen F, Leson G, Berghaus G, Drummer OH, Kruger HP, Longo M, et al. Developing limits for driving under cannabis. Addiction 2007;102(12):1910-7.

17. Bernhoft IM, Hels T, Lyckegaard A, Houwing S, Verstraete AG. Prevalence and risk of injury in Europe by driving with alcohol, illicit drugs and medicines. Procedia Soc Behav Sci 2012;48:290716.

18. Hels T, Lyckegaard A, Simonsen KW, Steentoft A, Bernhoft IM. Risk of severe driver injury by driving with psychoactive substances. Accid Anal Prev 2013;59:346-56.

19. Bogstrand ST, Gjerde H, Normann PT, Rossow I, Ekeberg O. Alcohol, psychoactive substances and non-fatal road traffic accidents-a case-control study. BMC Public Health 2012;12:734.

20. Gjerde $H$, Langel K, Favretto $D$, Verstraete AG. Estimation of equivalent cutoff thresholds in blood and oral fluid for drug prevalence studies. J Anal Toxicol 2014;38(2):92-8.

21. Gjerde H, Verstraete AG. Estimating equivalent cutoff thresholds for drugs in blood and oral fluid using prevalence regression: A study of tetrahydrocannabinol and amphetamine. Forensic Sci Int 2011;212(1-3):e26-e30.

22. Perttula A, Pitkaniemi J, Heinonen OP, Finkle WD, Triche T, Jr., Gergov M, et al. Secondgeneration antihistamines exhibit a protective effect on drivers in traffic-a preliminary population-based case-control study. Traffic Inj Prev 2014;15(6):551-5.

23. Hou CC, Chen SC, Tan LB, Chu WY, Huang CM, Liu SY, et al. Psychoactive substance use and the risk of motor vehicle crash injuries in southern Taiwan. Prev Sci 2012;13(1):36-42.

24. Movig KL, Mathijssen MP, Nagel PH, van Egmond T, de Gier JJ, Leufkens HG, et al. Psychoactive substance use and the risk of motor vehicle accidents. Accid Anal Prev 2004;36(4):631-6.

25. Romano E, Torres-Saavedra P, Voas RB, Lacey JH. Drugs and alcohol: their relative crash risk. J Stud Alcohol Drugs 2014;75(1):56-64.

26. Tourangeau R, Yan T. Sensitive questions in surveys. Psychol Bull 2007;133(5):859-83.

27. Krumpal I. Determinants of social desirability bias in sensitive surveys: a literature review. Qual Quant 2013;47:2025-47.

28. Kääriäinen JT. Trust in the police in 16 European countries. A multilevel analysis. Eur J Criminol 2007;4(4):409-35.

29. Mura P, Kintz P, Ludes B, Gaulier JM, Marquet P, Martin-Dupont S, et al. Comparison of the prevalence of alcohol, cannabis and other drugs between 900 injured drivers and 900 control subjects: results of a French collaborative study. Forensic Sci Int 2003;133(1-2):79-85.

30. Woratanarat $P$, Ingsathit A, Suriyawongpaisal P, Rattanasiri S, Chatchaipun $P$, Wattayakorn $K$, et al. Alcohol, illicit and non-illicit psychoactive drug use and road traffic injury in Thailand: a casecontrol study. Accid Anal Prev 2009;41(3):651-7.

31. Gjerde H, Øiestad EL, Christophersen AS. Using biological samples in epidemiological research on drugs of abuse. Nor Epidemiol 2011;21(1):5-14. 
32. Samyn N, Verstraete A, van Haeren C, Kintz P. Analysis of drugs of abuse in saliva. Forensic Sci Rev 1999;11(1):2-17.

33. Verstraete AG. Detection times of drugs of abuse in blood, urine, and oral fluid. Ther Drug Monit 2004;26(2):200-5.

34. Langel K, Gjerde H, Favretto D, Lillsunde P, Øiestad EL, Ferrara SD, et al. Comparison of drug concentrations between whole blood and oral fluid. Drug Test Anal 2014;6(5):461-71.

35. Wille SMR, Raes E, Lillsunde P, Gunnar T, Laloup M, Samyn N, et al. Relationship between oral fluid and blood concentrations of drugs of abuse in drivers suspected of DUID. Ther Drug Monit 2009;31(4):511-9.

36. Gjerde H, Langel K, Favretto D, Verstraete AG. Detection of 4 benzodiazepines in oral fluid as biomarker for presence in blood. Ther Drug Monit 2014;36(2):252-6.

37. Gjerde $H$, Langel K, Favretto D, Verstraete AG. Detection of illicit drugs in oral fluid from drivers as biomarker for drugs in blood. Forensic Sci Int 2015;256:42-5.

38. Cone EJ. Pharmacokinetics and pharmacodynamics of cocaine. J Anal Toxicol 1995;19(6):459-78.

39. Hartman RL, Brown TL, Milavetz G, Spurgin A, Gorelick DA, Gaffney GR, et al. Effect of Blood Collection Time on Measured Delta9-Tetrahydrocannabinol Concentrations: Implications for Driving Interpretation and Drug Policy. Clin Chem 2016;62(2):367-77.

40. Liechti ME, Quednow BB, Liakoni E, Dornbierer D, von Rotz R, Gachet MS, et al. Pharmacokinetics and pharmacodynamics of gamma-hydroxybutyrate in healthy subjects. $\mathrm{Br} \mathrm{J}$ Clin Pharmacol 2016;81(5):980-8.

41. Wood E, Brooks-Russell A, Drum P. Delays in DUI blood testing: Impact on cannabis DUI assessments. Traffic Inj Prev 2016;17(2):105-8.

42. Ferner RE. Post-mortem clinical pharmacology. Br J Clin Pharmacol 2008;66(4):430-43.

43. Han E, Kim E, Hong H, Jeong S, Kim J, In S, et al. Evaluation of postmortem redistribution phenomena for commonly encountered drugs. Forensic Sci Int 2012;219(1-3):265-71.

44. Rodda KE, Drummer OH. The redistribution of selected psychiatric drugs in post-mortem cases. Forensic Sci Int 2006;164(2-3):235-9.

45. Ashton CH. Benzodiazepine equivalence table 2007 [June 26, 2018]. Available from: http://www.benzo.org.uk/bzequiv.htm.

46. Altamura AC, Moliterno D, Paletta S, Maffini M, Mauri MC, Bareggi S. Understanding the pharmacokinetics of anxiolytic drugs. Expert Opin Drug Metab Toxicol 2013;9(4):423-40.

47. Shader RI, Greenblatt DJ. Can you provide a table of equivalences for benzodiazepines and other marketed benzodiazepine receptor agonists? J Clin Psychopharmacol 1997;17(4):331.

48. Reisine T, Pasternak GW. Opioid analgesics and antagonists. In: Hardman JG, Limbird LE, editors. Goodman \& Gilman's: The Pharmacological Basis of Therapeutics (9th Ed) New York, NY:

McGraw-Hill; 1996. p. 521-56.

49. Svendsen K, Borchgrevink P, Fredheim O, Hamunen K, Mellbye A, Dale O. Choosing the unit of measurement counts: the use of oral morphine equivalents in studies of opioid consumption is a useful addition to defined daily doses. Palliat Med 2011;25(7):725-32. 
50. Zacny JP. A review of the effects of opioids on psychomotor and cognitive functioning in humans. Exp Clin Psychopharmacol 1995;3(4):432-66.

51. Strand MC, Mørland J, Slordal L, Riedel B, Innerdal C, Aamo T, et al. Conversion factors for assessment of driving impairment after exposure to multiple benzodiazepines/z-hypnotics or opioids. Forensic Sci Int 2017;281:29-36.

52. Antin JF, Guo F, Fang Y, Dingus TA, Perez MA, Hankey JM. A validation of the low mileage bias using naturalistic driving study data. J Safety Res 2017;63:115-20.

53. Keall MD, Frith WJ. Characteristics and risks of drivers with low annual distance driven. Traffic Inj Prev 2006;7(3):248-55.

54. Beirness DJ, Simpson HM. Lifestyle correlates of risky driving and accident involvement among youth. Alcohol Drugs Driving 1988;4(3-4):193-219.

55. Bingham CR, Shope JT. Adolescent predictors of traffic crash patterns from licensure into early young adulthood. Annu Proc Assoc Adv Automot Med 2005;49:245-59.

56. Dunlop SM, Romer D. Adolescent and young adult crash risk: sensation seeking, substance use propensity and substance use behaviors. J AdolescHealth 2010;46(1):90-2.

57. Karjalainen K, Blencowe T, Lillsunde P. Substance use and social, health and safety-related factors among fatally injured drivers. Accid Anal Prev 2012;45:731-6.

58. Walter M, Hargutt V, Krüger HP. German Smartphone Survey Part II: Person-Related Characteristics of Drug Users and Drug Drivers Compared to Controls. DRUID Deliverable 2.2.2. Würzburg, Germany: University of Würzburg; 2012.

59. Gjerde $H$, Bogstrand ST, Lillsunde P. Why is the odds ratio for involvement in serious road traffic accident among drunk drivers in Norway and Finland higher than in other countries? Traffic Inj Prev 2014;15 (1):1-5.

60. Berkson J. Maximum likelihood and minimum chi-square estimates of the logistic function. J Amer Statist Assoc 1955;50:130-62.

61. Assum T, Mathijsen MPM, Houwing S, Buttress SC, Sexton B, Tunbridge RJ, et al. The prevalence of drug driving and relative risk estimations. A study conducted in The Netherlands, Norway and the United Kingdom. D-R4.2 ed. Vienna, Austria: Kuratorium für Verkehrssicherheit; 2005.

62. Pearce N. Analysis of matched case-control studies. BMJ 2016;352:i969.

63. Engeland A, Skurtveit S, Mørland J. Risk of road traffic accidents associated with the prescription of drugs: a registry-based cohort study. Ann Epidemiol 2007;17(8):597-602.

64. Neutel Cl. Risk of traffic accident injury after a prescription for a benzodiazepine. Ann Epidemiol 1995;5(3):239-44.

65. Asbridge M, Mann R, Cusimano MD, Trayling C, Roerecke M, Tallon JM, et al. Cannabis and traffic collision risk: findings from a case-crossover study of injured drivers presenting to emergency departments. Int J Public Health 2014;59(2):395-404.

66. Orriols L, Philip P, Moore N, Castot A, Gadegbeku B, Delorme B, et al. Benzodiazepine-like hypnotics and the associated risk of road traffic accidents. Clin Pharmacol Ther 2011;89(4):595601. 
67. Beirness DJ, Beasley EE, Boase P. A comparison of drug use by fatally injured drivers and drivers at risk. In: Watson B, editor. Proceedings of the 20th International Council on Alcohol, Drugs and Traffic Safety Conference. Brisbane, Australia: Center for Accident Research and Road Safety Queensland; 2013. p. 96-100.

68. Brault M, Dussault C, Bouchard J, Lemire AM. The contribution of alcohol and other drugs among fatally injured drivers in Quebec: final results. In: Oliver J, Williams P, Clayton A, editors. Proceedings of the 17th International Conference on Alcohol, Drugs and Traffic Safety (CD-ROM). Glasgow, UK: Scottish Executive; 2004.

69. Hels T, Bernhoft IM, Lyckegaard A, Houwing S, Hagenzieker M, Legrand SA, et al. Risk of injury by driving with alcohol and other drugs. DRUID Deliverable D 2.3.5. Copenhagen, Denmark: Technical University of Denmark; 2011.

70. Li G, Brady JE, Chen Q. Drug use and fatal motor vehicle crashes: a case-control study. Accid Anal Prev 2013;60:205-10.

71. Mathijssen R, Houwing $\mathrm{S}$. The prevalence and relative risk of drink and drug driving in the Netherlands: a case-control study in the Tilburg police district. Leidschendam, The Netherlands: SWOV; 2005. 
Table 1. Case-control studies on drug use (as exposure factor) and being injured in a road traffic crash (as outcome)

\begin{tabular}{|c|c|c|c|c|c|c|c|c|c|c|c|c|}
\hline \multirow[b]{2}{*}{ Authors, year, country } & \multicolumn{5}{|c|}{ Selection of cases and controls } & \multicolumn{4}{|c|}{ Assessing drug exposure } & \multicolumn{3}{|l|}{ Statistics } \\
\hline & Cases & $\begin{array}{l}\text { Partici- } \\
\text { pation } \\
\text { rate }(\%)\end{array}$ & Controls & $\begin{array}{l}\text { Partici- } \\
\text { pation } \\
\text { rate (\%) }\end{array}$ & $\begin{array}{l}\text { Selection } \\
\text { bias }\end{array}$ & $\begin{array}{l}\text { Biological } \\
\text { samples }\end{array}$ & $\begin{array}{l}\text { Same or } \\
\text { equivalent } \\
\text { for cases } \\
\text { and } \\
\text { controls }\end{array}$ & $\begin{array}{l}\text { Likely } \\
\text { infor- } \\
\text { mation } \\
\text { bias }\end{array}$ & $\begin{array}{l}\text { Drug } \\
\text { exposure } \\
\text { level is clearly } \\
\text { described }\end{array}$ & $\begin{array}{l}\text { Statistical } \\
\text { approach }\end{array}$ & Covariates & $\begin{array}{l}\text { Statistical } \\
\text { methods } \\
\text { clearly } \\
\text { described }\end{array}$ \\
\hline $\begin{array}{l}\text { Assum et al. (2015), } \\
\text { Norway (61) }\end{array}$ & $\begin{array}{l}87 \\
\text { killed or } \\
\text { injured } \\
\text { car/van/ } \\
\text { minibus } \\
\text { drivers }\end{array}$ & Unkn & $\begin{array}{l}410 \\
\text { drivers in } \\
\text { normal } \\
\text { traffic }\end{array}$ & 87 & Likely & $\begin{array}{l}\text { Alcohol: B } \\
\text { or BR } \\
\text { Drugs: B } \\
\text { (cases); } \\
\text { OF } \\
\text { (controls) }\end{array}$ & No & $\begin{array}{l}\text { CC, SYE, } \\
\text { RE }\end{array}$ & $\begin{array}{l}\text { Cut-offs } \\
\text { presented; } \\
\text { not explained }\end{array}$ & $\begin{array}{l}\text { Bivariate } \\
\text { SS, SG, SC } \\
\text { Ref: NSU }\end{array}$ & None & Yes \\
\hline $\begin{array}{l}\text { Beirness et al. (2013), } \\
\text { Canada (67) }\end{array}$ & $\begin{array}{l}902 \\
\text { fatally } \\
\text { injured } \\
\text { drivers }^{a}\end{array}$ & Unkn & 4,711 & 68.4 & Likely & $\begin{array}{l}\text { Alcohol: B } \\
\text { or BR } \\
\text { Drugs: B } \\
\text { (cases); } \\
\text { OF } \\
\text { (controls) }\end{array}$ & No & $\begin{array}{l}\text { CC, SYE, } \\
\text { RE }\end{array}$ & $\begin{array}{l}\text { Cut-offs not } \\
\text { presented }\end{array}$ & $\begin{array}{l}\text { Bivariate. } \\
\text { SS, SC } \\
\text { Ref: NSU }\end{array}$ & None & No \\
\hline $\begin{array}{l}\text { Bogstrand et al. (2012), } \\
\text { Norway (19) }\end{array}$ & $\begin{array}{l}96 \\
\text { injured } \\
\text { car/van } \\
\text { drivers }\end{array}$ & 93 & $\begin{array}{l}, 305 \\
\text { drivers in } \\
\text { normal } \\
\text { traffic }\end{array}$ & 93.8 & Likely & $\begin{array}{l}\text { Cases: B } \\
\text { Controls: } \\
\text { OF }\end{array}$ & Yes & $\begin{array}{l}\text { CC, SYE, } \\
\text { RE }\end{array}$ & $\begin{array}{l}\text { Cut-offs } \\
\text { presented; } \\
\text { not explained }\end{array}$ & $\begin{array}{l}\text { Bivariate and } \\
\text { Multivariable, } \\
\text { SC } \\
\text { Ref: NSU }\end{array}$ & age & Yes \\
\hline $\begin{array}{l}\text { Brault et al. (2014), } \\
\text { Canada (68) }\end{array}$ & $\begin{array}{l}512 \\
\text { killed } \\
\text { passenger } \\
\text { vehicles } \\
\text { drivers }\end{array}$ & 38.3 & $\begin{array}{l}5,931 \\
\text { drivers in } \\
\text { normal } \\
\text { traffic }\end{array}$ & 49.6 & Likely & $\begin{array}{l}\text { Alcohol: B } \\
\text { or BR } \\
\text { Drugs: U }\end{array}$ & Yes & CC & $\begin{array}{l}\text { Cut-offs } \\
\text { presented; } \\
\text { explained }\end{array}$ & $\begin{array}{l}\text { Bivariate and } \\
\text { Multivariable, } \\
\text { SS, SG, SC } \\
\text { Ref: not } \\
\text { defined }\end{array}$ & $\begin{array}{l}\text { age, sex, } \\
\text { tim }\end{array}$ & No \\
\hline $\begin{array}{l}\text { Gjerde et al. (2011), } \\
\text { Norway (13) }\end{array}$ & $\begin{array}{l}204 \\
\text { killed } \\
\text { car/van } \\
\text { drivers }\end{array}$ & 61 & $\begin{array}{l}10,540 \\
\text { drivers in } \\
\text { normal } \\
\text { traffic }\end{array}$ & 88 & Likely & $\begin{array}{l}\text { Cases: B } \\
\text { Controls: } \\
\text { OF }\end{array}$ & Yes & $\mathrm{CC}, \mathrm{RE}$ & $\begin{array}{l}\text { Cut-offs } \\
\text { presented; } \\
\text { not explained }\end{array}$ & $\begin{array}{l}\text { Bivariate and } \\
\text { Multivariable, } \\
\text { SS, SG, SC } \\
\text { Ref: not } \\
\text { defined }\end{array}$ & $\begin{array}{l}\text { age, sea, } \\
\text { sex, tim }\end{array}$ & No \\
\hline $\begin{array}{l}\text { Gjerde et al. (2013), } \\
\text { Norway (14) }\end{array}$ & $\begin{array}{l}508 \\
\text { killed } \\
\text { car/van } \\
\text { drivers }\end{array}$ & 61 & $\begin{array}{l}9,261 \\
\text { drivers in } \\
\text { normal } \\
\text { traffic }\end{array}$ & 94 & Likely & $\begin{array}{l}\text { Cases: B } \\
\text { Controls: } \\
\text { OF }\end{array}$ & Yes & $\mathrm{CC}, \mathrm{RE}$ & $\begin{array}{l}\text { Cut-offs } \\
\text { presented; } \\
\text { partly } \\
\text { explained }\end{array}$ & $\begin{array}{l}\text { Bivariate and } \\
\text { Multivariable, } \\
\text { SS, SG, SC } \\
\text { Ref: not } \\
\text { defined }\end{array}$ & $\begin{array}{l}\text { age, geo, } \\
\text { sea, sex, } \\
\text { tim, urb }\end{array}$ & No \\
\hline
\end{tabular}




\begin{tabular}{|c|c|c|c|c|c|c|c|c|c|c|c|c|}
\hline \multirow[b]{2}{*}{ Authors, year, country } & \multicolumn{5}{|c|}{ Selection of cases and controls } & \multicolumn{4}{|c|}{ Assessing drug exposure } & \multicolumn{3}{|l|}{ Statistics } \\
\hline & Cases & $\begin{array}{l}\text { Partici- } \\
\text { pation } \\
\text { rate (\%) }\end{array}$ & Controls & $\begin{array}{l}\text { Partici- } \\
\text { pation } \\
\text { rate (\%) }\end{array}$ & $\begin{array}{l}\text { Selection } \\
\text { bias }\end{array}$ & $\begin{array}{l}\text { Biological } \\
\text { samples }\end{array}$ & $\begin{array}{l}\text { Same or } \\
\text { equivalent } \\
\text { for cases } \\
\text { and } \\
\text { controls }\end{array}$ & $\begin{array}{l}\text { Likely } \\
\text { infor- } \\
\text { mation } \\
\text { bias }\end{array}$ & $\begin{array}{l}\text { Drug } \\
\text { exposure } \\
\text { level is clearly } \\
\text { described }\end{array}$ & $\begin{array}{l}\text { Statistical } \\
\text { approach }\end{array}$ & Covariates & $\begin{array}{l}\text { Statistical } \\
\text { methods } \\
\text { clearly } \\
\text { described }\end{array}$ \\
\hline $\begin{array}{l}\text { Hels et al. (2011) (69) } \\
\text { Bernhoft et al. (2012) } \\
\text { (17) } \\
\text { Europe (4 countries) }\end{array}$ & $\begin{array}{l}1112 \\
\text { killed } \\
\text { car/van } \\
\text { drivers }\end{array}$ & $\begin{array}{l}\text { FI } 94.3 \\
\text { NO } 59 \\
\text { PT } 79 \\
\text { SE } 94\end{array}$ & $\begin{array}{l}21,917 \\
\text { drivers in } \\
\text { normal } \\
\text { traffic }\end{array}$ & $\begin{array}{l}\text { FI } 52 \\
\text { NO } 94 \\
\text { PT } 97 \\
\text { SE } 62\end{array}$ & Likely & $\begin{array}{l}\text { Alcohol: B } \\
\text { or BR } \\
\text { Drugs: B } \\
\text { (cases); } \\
\text { OF } \\
\text { (controls) } \\
\end{array}$ & Yes & $\mathrm{CC}, \mathrm{RE}$ & $\begin{array}{l}\text { Cut-offs } \\
\text { presented; } \\
\text { not explained }\end{array}$ & $\begin{array}{l}\text { Bivariate and } \\
\text { Multivariable, } \\
\text { SS, SG, SC } \\
\text { Ref: NSU }\end{array}$ & $\begin{array}{l}\text { age, geo, } \\
\text { sex }\end{array}$ & Yes \\
\hline $\begin{array}{l}\text { Hels et al. (2011) (69) } \\
\text { Hels et al. (2013) (18) } \\
\text { Bernhoft et al. (2012) } \\
\text { (17) } \\
\text { Europe (6 countries) }\end{array}$ & $\begin{array}{l}2490 \\
\text { injured } \\
\text { car/van } \\
\text { drivers }\end{array}$ & $\begin{array}{l}\text { BE } 94.6 \\
\text { DK } 95 \\
\text { FI } 91.5 \\
\text { IT } 100 \\
\text { LT } 100 \\
\text { NL Unkn }\end{array}$ & $\begin{array}{l}15,832 \\
\text { drivers in } \\
\text { normal } \\
\text { traffic }\end{array}$ & $\begin{array}{l}\text { BE } 48 \\
\text { DK } 95 \\
\text { FI } 52 \\
\text { IT } 100 \\
\text { LT } 76 \\
\text { NL } 95\end{array}$ & Likely & $\begin{array}{l}\text { Alcohol: B } \\
\text { or BR. } \\
\text { Drugs: B } \\
\text { (cases); } \\
\text { B or OF } \\
\text { (controls) }\end{array}$ & Yes & CC, RE & $\begin{array}{l}\text { Cut-offs } \\
\text { presented; } \\
\text { not explained }\end{array}$ & $\begin{array}{l}\text { Bivariate and } \\
\text { Multivariable, } \\
\text { SS, SG, SC } \\
\text { Ref: NSU }\end{array}$ & $\begin{array}{l}\text { age, geo, } \\
\text { sex }\end{array}$ & Yes \\
\hline $\begin{array}{l}\text { Hou et al. (2012), Taiwan } \\
\text { (23) }\end{array}$ & $\begin{array}{l}254 \\
\text { Injured } \\
\text { car/van } \\
\text { drivers }\end{array}$ & 93 & $\begin{array}{l}254 \\
\text { drivers in } \\
\text { normal } \\
\text { traffic }\end{array}$ & 76 & Likely & $\begin{array}{l}\text { Alcohol: B } \\
\text { or BR } \\
\text { Drugs: B } \\
\text { or U }\end{array}$ & No & $C C ; S Y E^{b}$ & $\begin{array}{l}\text { U cut-offs } \\
\text { presented; } \\
\text { not explained }\end{array}$ & $\begin{array}{l}\text { Multivariable, } \\
\text { SS, SG, SC } \\
\text { Ref: NSU }\end{array}$ & $\begin{array}{l}\text { age, alc, } \\
\text { amp, bar, } \\
\text { ben, geo, } \\
\text { mar, sex, } \\
\text { tca, tim }\end{array}$ & Yes \\
\hline $\begin{array}{l}\text { Kuypers et al. (2012), } \\
\text { Belgium (15) }\end{array}$ & $\begin{array}{l}337 \\
\text { injured } \\
\text { car/van } \\
\text { drivers }\end{array}$ & $86.3^{c}$ & $\begin{array}{l}2,726 \\
\text { drivers in } \\
\text { normal } \\
\text { traffic }\end{array}$ & 44.8 & Likely & $\begin{array}{l}\text { Alcohol: } \\
\text { BR } \\
\text { Drugs: B }\end{array}$ & Yes & $\mathrm{CC}$ & $\begin{array}{l}\text { Cut-offs } \\
\text { presented; } \\
\text { not explained }\end{array}$ & $\begin{array}{l}\text { Bivariate and } \\
\text { Multivariable, } \\
\text { SS, SG, SC } \\
\text { Ref: not } \\
\text { defined }\end{array}$ & $\begin{array}{l}\text { age, sex, } \\
\text { tim }\end{array}$ & No \\
\hline Li et al. (2013), USA (70) & $\begin{array}{l}737 \\
\text { killed } \\
\text { drivers }^{\text {a }}\end{array}$ & 35.6 & $\begin{array}{l}7,719 \\
\text { drivers in } \\
\text { normal } \\
\text { traffic }\end{array}$ & 70.7 & Likely & $\begin{array}{l}\text { Alcohol: B } \\
\text { or BR } \\
\text { Drugs: B } \\
\text { or U } \\
\text { (cases); } \\
\text { OF } \\
\text { (controls) }\end{array}$ & No & CC, SYE & $\begin{array}{l}\text { Cut-offs not } \\
\text { presented; } \\
\text { not explained }\end{array}$ & $\begin{array}{l}\text { Bivariate } \\
\text { SS, SG, SC } \\
\text { Ref: NUSS }\end{array}$ & & Yes \\
\hline $\begin{array}{l}\text { Mathijssen and Houwing } \\
\text { (2015), The Netherlands } \\
\text { (71) }\end{array}$ & $\begin{array}{l}184 \\
\text { injured } \\
\text { drivers }^{a}\end{array}$ & 88.9 & $\begin{array}{l}3374 \\
\text { drivers in } \\
\text { normal } \\
\text { traffic }\end{array}$ & 87.6 & Likely & $\begin{array}{l}\text { Alcohol: B } \\
\text { or BR } \\
\text { Drugs: B } \\
\text { (cases); B, }\end{array}$ & No & $\begin{array}{l}\text { CC, SYE, } \\
\text { RE }\end{array}$ & $\begin{array}{l}\text { Cut-offs } \\
\text { presented; } \\
\text { not explained }\end{array}$ & $\begin{array}{l}\text { Bivariate } \\
\text { SS, SG, SC } \\
\text { Ref: NSU }\end{array}$ & None & Yes \\
\hline
\end{tabular}




\begin{tabular}{|c|c|c|c|c|c|c|c|c|c|c|c|c|}
\hline \multirow[b]{2}{*}{ Authors, year, country } & \multicolumn{5}{|c|}{ Selection of cases and controls } & \multicolumn{4}{|c|}{ Assessing drug exposure } & \multicolumn{3}{|l|}{ Statistics } \\
\hline & Cases & $\begin{array}{l}\text { Partici- } \\
\text { pation } \\
\text { rate (\%) }\end{array}$ & Controls & $\begin{array}{l}\text { Partici- } \\
\text { pation } \\
\text { rate (\%) }\end{array}$ & $\begin{array}{l}\text { Selection } \\
\text { bias }\end{array}$ & $\begin{array}{l}\text { Biological } \\
\text { samples }\end{array}$ & $\begin{array}{l}\text { Same or } \\
\text { equivalent } \\
\text { for cases } \\
\text { and } \\
\text { controls }\end{array}$ & $\begin{array}{l}\text { Likely } \\
\text { infor- } \\
\text { mation } \\
\text { bias }\end{array}$ & $\begin{array}{l}\text { Drug } \\
\text { exposure } \\
\text { level is clearly } \\
\text { described }\end{array}$ & $\begin{array}{l}\text { Statistical } \\
\text { approach }\end{array}$ & Covariates & $\begin{array}{l}\text { Statistical } \\
\text { methods } \\
\text { clearly } \\
\text { described }\end{array}$ \\
\hline & & & & & & $\begin{array}{l}\mathrm{U} \\
\text { (controls) }\end{array}$ & & & & & & \\
\hline $\begin{array}{l}\text { Movig et al. (2004), The } \\
\text { Netherlands (24) }\end{array}$ & $\begin{array}{l}110 \\
\text { injured } \\
\text { car/van } \\
\text { drivers }\end{array}$ & Unkn & $\begin{array}{l}816 \\
\text { drivers in } \\
\text { normal } \\
\text { traffic }\end{array}$ & 79.3 & Likely & $\begin{array}{l}\text { Alcohol: B } \\
\text { or BR } \\
\text { Drugs: B } \\
\text { or U }\end{array}$ & Yes & CC, SYE & $\begin{array}{l}\text { Cut-offs not } \\
\text { presented; } \\
\text { not explained }\end{array}$ & $\begin{array}{l}\text { Multivariable, } \\
\text { SS, SG, SC } \\
\text { Ref: NSU }\end{array}$ & $\begin{array}{l}\text { age, alc, } \\
\text { amp, ben, } \\
\text { can, coc, } \\
\text { opi, sea, } \\
\text { sex, tim } \\
\end{array}$ & Yes \\
\hline $\begin{array}{l}\text { Mura et al. (2003), } \\
\text { France (29) }\end{array}$ & $\begin{array}{l}900 \\
\text { Injured } \\
\text { car drivers }\end{array}$ & 96 & $\begin{array}{l}900 \\
\text { non- } \\
\text { trauma } \\
\text { patients }\end{array}$ & 96 & Likely & $\begin{array}{l}\text { B and } \\
\text { either } \mathrm{U} \\
\text { or SW }\end{array}$ & Yes & $\mathrm{CC}$ & $\begin{array}{l}\text { Some } \\
\text { cut-offs } \\
\text { presented,; } \\
\text { not explained }\end{array}$ & $\begin{array}{l}\text { Matching } \\
\text { SS, SG, SC } \\
\text { Ref: not } \\
\text { defined }\end{array}$ & age, sex & No \\
\hline $\begin{array}{l}\text { Perttula et al. (2014), } \\
\text { Finland (22) }\end{array}$ & $\begin{array}{l}427 \\
\text { killed } \\
\text { drivers }^{a}\end{array}$ & Unkn & $\begin{array}{l}687 \\
\text { drivers at } \\
\text { petrol } \\
\text { station }\end{array}$ & 63.4 & Likely & $\begin{array}{l}\text { Cases: B } \\
\text { Controls: } \\
\mathrm{B}, \mathrm{Q}\end{array}$ & Yes & CC, SYE & $\begin{array}{l}\text { Cut-offs } \\
\text { presented; } \\
\text { explained }\end{array}$ & $\begin{array}{l}\text { Matching } \\
\text { Multivariable } \\
\text { (age) } \\
\text { SG } \\
\text { Ref: NUSS } \\
\end{array}$ & $\begin{array}{l}\text { age, geo, } \\
\text { sea, sex }\end{array}$ & Yes \\
\hline $\begin{array}{l}\text { Romano et al. (2014), } \\
\text { USA (25) }\end{array}$ & $\begin{array}{l}1,766 \\
\text { killed car } \\
\text { drivers }\end{array}$ & Unkn & $\begin{array}{l}3,424 \\
\text { drivers in } \\
\text { normal } \\
\text { traffic }\end{array}$ & 71 & Likely & $\begin{array}{l}\text { Alcohol: B } \\
\text { or BR } \\
\text { Drugs: B } \\
\text { or U } \\
\text { (cases) } \\
\text { and OF } \\
\text { (controls) }\end{array}$ & No & $\begin{array}{l}\text { CC, SYE, } \\
\text { RE }\end{array}$ & $\begin{array}{l}\text { Cut-offs not } \\
\text { presented; } \\
\text { not explained }\end{array}$ & $\begin{array}{l}\text { Bivariate and } \\
\text { Multivariable } \\
\text { SS, SG } \\
\text { Ref: NSU }\end{array}$ & $\begin{array}{l}\text { age, alc, } \\
\text { dru, eth, } \\
\text { sex }\end{array}$ & Yes \\
\hline $\begin{array}{l}\text { Woratanarat et al. } \\
\text { (2009), Thailand (30) }\end{array}$ & $\begin{array}{l}200 \\
\text { injured } \\
\text { motor } \\
\text { vehicle } \\
\text { drivers } \\
\end{array}$ & 17 & $\begin{array}{l}849 \\
\text { drivers at } \\
\text { petrol } \\
\text { station }\end{array}$ & 53 & Likely & $\begin{array}{l}\text { Alcohol: B } \\
\text { or BR } \\
\text { Drugs: U }\end{array}$ & Yes & $\begin{array}{l}\text { Not } \\
\text { signifi- } \\
\text { cant }\end{array}$ & $\begin{array}{l}\text { Cut-offs } \\
\text { presented; } \\
\text { explained }\end{array}$ & $\begin{array}{l}\text { Matching } \\
\text { Multivariable } \\
\text { SS, SG } \\
\text { Ref: NUSS }\end{array}$ & $\begin{array}{l}\text { alc, ill, nil, } \\
\text { ndt, sex, } \\
\text { tim, yod }\end{array}$ & Yes \\
\hline
\end{tabular}

${ }^{a}$ The term "driver" may include motorcycle or moped riders. ${ }^{b}$ Different proportion of blood and urine samples among cases than among controls. ${ }^{\mathrm{C}}$ Before excluding non-eligible drivers.

Selection of cases and controls. Unkn = unknown; NRS = non-representative selection of cases or controls. Country abbreviations: BE = Belgium; DK = Denmark; FI = Finland; IT = Italy, LT = Lithuania; NL = The Netherlands; NO = Norway; PT = Portugal; SE = Sweden. 
Assessing drug exposure. Samples: $\mathrm{B}=$ blood; $\mathrm{BR}=$ breath; $\mathrm{OF}=$ oral fluid; $\mathrm{SW}=$ sweat; $\mathrm{U}=$ urine. Likely information bias: $\mathrm{CC}=$ concentration change in cases before sample collection; SYE = Systematic error in exposure classification due to different exposure definition for cases than for controls; RE = Random errors in exposure classification due to use of oral fluid.

Statistics. Approach: SC = substance combinations; SG = substance group use; $\mathrm{SS}=$ single substance use; NSU = no substance use; NUSS = no use of the studied substance; Ref $=$ reference group. Covariates: age = age of driver; alc = alcohol used; amp = amphetamines; bar = barbiturates; ben =

benzodiazepines; dru = drugs; eth = ethnicity; geo = geographical area; ill = illicit drugs; mar = marital status; ndt = non-stop driving time; nil = non-illicit drugs; sea = season of the year; tca = tricyclic antidepressants; tim = time of day or week; urb = urbanity; yod - years of driving. 